\title{
Detection and Identification of Plant Growth Promoting Bacteria from Sorghum (Sorghum bicolor L. Moench) Rhizosphere Soil in Northern Ethiopia
}

\author{
Birhanu Babiye $^{1 *}$, Beira H. Meressa ${ }^{2}$ and Taye Tessema ${ }^{3}$ \\ ${ }^{1}$ Ethiopian Institute of Agricultural Research, National Agricultural \\ Biotechnology Research Center, Plant Biotechnology program, Holeta, Ethiopia. \\ ${ }^{2}$ Department of Horticulture and Plant Science, College of Agriculture and Veterinary Medicine, \\ Jimma University, Jimma, Ethiopia. \\ ${ }^{3}$ Ethiopian Institute of Agricultural Research, National Project Coordinator, \\ Integrated Striga Control Project, Addis Ababa, Ethiopia. \\ http://dx.doi.org/10.13005/bbra/2935
}

(Received: 10 August 2021; accepted: 12 October 2021)

Plant growth promoting rhizobacteria are the bacteria which subsist inside and outside of the plant tissue and promote plant growth through direct or indirect mechanisms. To increase sorghum production and productivity we utilize herbicides and chemical fertilizers to overcome sorghum production constraints, but those chemicals have negative side effects. The current study was conducted with the objective of isolation of PGPR from sorghum rhizosphere and screening for primary growth related trait, evaluation of potential PGPR at greenhouse for sorghum growth performance and identify through biochemical characterization. So that, in this study a total of 117 plant growth promoting rhizobacteria were isolated from the rhizosphere of 12 sorghum (Sorghum bicolor L. Moench) genotype by cultivating using 3 collected soil samples from the northern part of Ethiopia (Amhara and Tigray regional states) in greenhouse. Isolated bacteria were screened for primary growth promoting traits such as phosphate solubilization test, IAA production test at different concentration of L-tryptophan and ammonia production test. From the isolated bacteria $28 \%$ solubilized Phosphorous, $78 \%$ produced IAA at different concentration of tryptophan. The greatest IAA production was scored at $100 \mathrm{mg} / \mathrm{L} \mathrm{of} \mathrm{tryptophan}$ and the lowest production of IAA was scored at $150 \mathrm{mg} / \mathrm{L} \mathrm{of} \mathrm{tryptophan,} 69 \%$ of isolated bacteria produced ammonia. Hence, $15 \%$ of isolated bacteria fulfilled the above primary screening test and used for further greenhouse evaluation. Accordingly, eighteen bacteria were tested for greenhouse experiment using completely randomized design and all 18 isolates were significantly increased all the agronomic parameter as compared to the control such as plant shoot height, plant shoot fresh and dry weight, root length, root fresh and dry weight at $p<$ 0.01 and $P=0.001$. Two isolates G6E29 and G4E19 had significantly increased all the parameter but two isolates (G12E19 and G3E40) were statistically non-significant for root fresh weight compared to the control. These 18 potential isolates were characterized morphologically and biochemically. Eight isolates were grouped at Pseudomonas genera. Six isolates were grouped at Azotobacter and the rest four isolates were grouped at Bacillus genera. Thus, the use of plant growth promoting rhizosphere bacteria could be useful to improve sorghum production and productivity. However, further molecular identification and evaluation of the isolates exhibiting multiple plant growths promoting traits on plant-microbe interaction for economic crop of Ethiopia is needed to uncover their efficacy as effective plant growth promoting rhizosphere bacteria.

Keywords: Phytohormones; Plant Microbiome; Metabolites; Metagenomics. 
Sorghum (Sorghum bicolor L. Moench) belongs to the family Poaceae (Gramineae) with a global ranking of fifth most important staple cereal food crop after wheat, rice, maize and barley. It is also a staple food for more than 500 million people in more than 30 countries of semi-arid area of the world. ${ }^{13,20,25}$

Sorghum domestication started at the north east quadrant of Africa, specifically in Ethiopian western part usually known as EthioSudanese border region due to its unique adaptation to harsh and drought-prone environments. The total sorghum production in sorghum producing areas of the world is 55.6 million tons, and world average yield was 1.37 tons per ha in 2020. Sorghum is the second staple food next to maize for sub Saharan countries, were 18 million tons is produced annually from 27 million ha. ${ }^{15,22,25}$

The food and agricultural organization ${ }^{15}$ reported the United States of America is the top sorghum producer with about 9.7 million tons, followed by India, Nigeria, Sudan, and Ethiopia. In Ethiopia, sorghum is the fourth staple food crop both in area coverage and production after teff, maize and wheat. The crop is grown in almost all regions with estimated total land area of 1.8 million hectares. ${ }^{11}$

The major sorghum producing regions of Ethiopia are Oromia, Amhara, Tigray, and southern nation, nationality and peoples. Compared to other African countries, Ethiopian sorghum productivity is very low with an average productivity of 2.7 tons per ha. This low productivity needs sorghum improvement to increase productivity to achieve food security. ${ }^{11,17,20}$ Both abiotic and biotic factors; such as drought, low soil fertility, insects, quelea bird and Striga weed are the major production constraints affecting sorghum productivity. ${ }^{16,24}$

In Ethiopia, the most known biotic production constraint is Striga (Striga hermonthica) affecting by its association with the root of sorghum causing annual losses of up to 7 billion USD, which is considered to affect the livelihood of 300 million people due to a decrease in sorghum production and productivity. $^{7}$

To increase sorghum growth and grain yield by decreasing the impact of striga on sorghum, farmers and researchers have been using herbicides and chemical fertilizers, but these chemicals, in addition to their positive effect in promoting plant growth and increasing sorghum grain yield, have negative side effects in that they pollute the environment and decrease soil microbial diversity by killing them through increasing soil $\mathrm{pH}^{3,23,35}$

In addition to utilization of herbicide and chemical fertilizer in an effort to reduce the impact of striga on sorghum productivity, several researches have been conducted with the goal of developing steriga tolerant varieties using conventional breeding practice. Despite these efforts, the problem still exist. The new approach to solve steriga constraint on sorghum production, these days, is on the interaction of steriga weed, sorghum and soil microbes. ${ }^{?}$

Beneficial bacteria which inhabit the soil rhizosphere of plant can manage soil environment to achieve attainable crop yield. Bacteria use exudates that are secreted by plant roots within the rhizosphere. They influence plant in a direct or indirect mechanism. Stimulation of plant growth is considered to be one of the influences on plants by soil bacteria. Rhizosphere bacteria that influence plant growth positively are referred to as plant growth promoting rhizobacteria, due to their effect on crop yield increase. ${ }^{8,10}$

There are a lot of factors that affect plant growth promoting rhizosphere bacteria; such as environmental condition, plant genotype, soil type, soil and field condition and green house condition. The prominent factors that affect PGPR's function to promote plant growth are plant genotype and soil type. Genotype of plant secrete root exudates compound that differs among plant genotypes and the function of exudates compound also differs from soil to soil type and condition. $5,19,39$

Plant growth promoting rhizobacteria can be helpful to plants either by increasing the availability of both macro and micro elements; such as nitrogen, phosphorus, iron and zinc in the rhizosphere producing plant growth promoting (PGP) substances; such as indole acetic acid and siderophore production. ., 21, 28, 39

Currently, there is an increasing interest on understanding the natural relationship between sorghum with PGPRs to develop growth promoting rhizobacteria as inoculants to supplement chemical fertilizers. In Ethiopia, there has been an attempt 
by ${ }^{25,37}$ regarding on the utilization of rhizosphere bacteria for promoting sorghum and teff growth as biofertilizer inoculants.

The growing interest in the use of plant growth promoting bacteria as inoculants for sorghum growth promoting was limited in Ethiopia, and had a little scientific justification and very limited studies on the potential role of PGPRs as plant growth promoting agents, which PGPRs are effectively associated with specific sorghum genotype are not studied well. Having those gaps about plant growth promoting rhizobacteria in Ethiopia, the current study; therefore, focused on the following objectives, such as isolation of PGPR bacteria from sorghum rhizosphere soil, and screen for growth prompting trait, determination of the effect of selected bacterial isolates on sorghum growth performance in Greenhouse and identification of effective growth promoting bacteria through biochemical characterization.

\section{MATERIALS AND METHODS}

\section{Soil Sampling for Isolation of Growth Promoting Bacteria}

A total of 46 soil samples were collected randomly from the northern part of Ethiopia (Tigray and Amhara regions) in which sorghum is frequently cultivated for daily consumption of people which inhabited in the area. Lists of areas from which the samples are collected is presented in (Table 1).

\section{Rhizosphere Soil Sampling}

Plant growth- promoting rhizosphere bacteria were isolated from 12 sorghum genotypes (Table 3) using 3 soil samples from a total of 46 random soil samples. The selection was based on their PGPR bacterial diversity using metagenomics tool in which both cultivable and uncultivable soil microbes by DNA extraction directly from their environmental sample. All the 12 sorghum genotypes were cultivated in the NABRC greenhouse at Holeta in the three 3 soil samples by adding $700 \mathrm{~g}$ soil to $800 \mathrm{~g}$ capacity plastic pot. All sorghum genotypes were grown in 4 replications by sowing two seeds per pot.

Sorghum seeds were first surface sterilized by adding 5\% local bleach (sodium hypochlorite) for 30 seconds followed by $1.5 \%$ Tween 20 . The seeds were then washed by sterilized water five times and germinated on Whatman paper on a plate. Finally, the seedlings were transferred to pots in the greenhouse and allowed to grow for 40 days.

\section{Isolation of PGPR Bacteria}

To isolate PGPR bacteria, all cultivated 12 sorghum genotypes were harvested at the same time after 40 days in greenhouse and the roots were cut from the stem using a sterilized surgical blade. Then, all roots were put into falcon tubes which had $35 \mathrm{ml}$ of sterilized $0.85 \%$ saline water. The Falcon tube was shaken on a shaker for 30 minutes to wash the rhizosphere bacteria. Then, the samples were centrifuged at 10,000 rpm for 10 $\mathrm{min}$, and roots were transferred to another falcon tube which contained $35 \mathrm{ml}$ sterilized saline water. After that, the second tube was centrifuged, and the roots were put into another falcon tube. Finally, the two-round pellets were mixed by removing the supernatant. The mixed pellets were used to isolate PGPR bacteria.

One gram (1g) of pellet suspension was taken and transferred to $9 \mathrm{ml}$ of sterilized $85 \%$ saline solution. The serial dilution continued up to $1 \times 10^{-8}$ by taking $1000 \mu \mathrm{l}$ of diluted sample and was poured to the nutrient agar plate media from the dilution factor of $1 \times 10^{-4}, 1 \times 10^{-5}$ and $1 \times 10^{-6}$ by taking $100 \mu \mathrm{l}$ of diluted sample and by spreading plate method in 3 replications for each.

The plates were then incubated at $28^{\circ} \mathrm{C}$ for 2 days. Individual bacterial colonies were selected and subculture on nutrient agar seven times for purification. Hence, a total of 117 pure bacterial isolates were obtained by sub culturing.

Then for each isolate, two copies were made; one copy for long term preservation in $40 \%$ glycerol at $-80^{\circ} \mathrm{c}$ and another copy stored in $4^{\circ} \mathrm{C}$ refrigerators for the active work. All the 117 isolates were tested for primary screening of related trait as followed.

\section{Detection of Plant Growth Promoting Traits Phosphate Solubilization Test}

Phosphate solubilization activity of plant growth promoting rhizosphere bacterial isolates were detected in plate assay method using Pikovaskaya (PVK) agar following method described. ${ }^{31}$. A loop full pure fresh overnight culture isolate was streaked on the Pikovaskaya (PVK) agar media in three replications. PVK agar medium contained: glucose $=10 \mathrm{~g} ; \mathrm{Ca}_{3}\left(\mathrm{PO}_{4}\right)_{2}=5 \mathrm{~g} ;\left(\mathrm{NH}_{4}\right)$ $\mathrm{SO}_{4}=0.5 \mathrm{~g} ; \mathrm{NaCl}=0.2 \mathrm{~g} ; \mathrm{MgSO}_{4} .7 \mathrm{H}_{2} \mathrm{O}=0.1 \mathrm{~g}$; 
$\mathrm{KCl}=0.2 \mathrm{~g} ; \mathrm{NaCl}=0.2 \mathrm{~g} ; \mathrm{MnSO}_{4} \cdot \mathrm{H}_{2} \mathrm{O}=0.002$ $\mathrm{g} ; \mathrm{FeSO}_{4} \cdot 7 \mathrm{H}_{2} \mathrm{O}=0.002 \mathrm{~g}$ and yeast extract $=0.5$ $\mathrm{g}$ per liter of a media.

The plates were incubated for 18 days at $28^{\circ} \mathrm{C}$ after which the isolate that could make a clear hallo zone was selected. Plates without streak of isolates were used as a control. The clear hallo zone of the isolate was measured millimeter ( $\mathrm{mm})$. The isolate differentiation was made using phosphate solubilization index calculated with the following formula.

Phosphate solubilization index $=$ [ colonydiameter + clearhallozonediameter] / colonydiameter

\section{IAA Production Test}

Isolates that have the potential to solubilize the phosphate were selected and tested for the Production of IAA by using the method described ${ }^{36}$, With a replication of 3 for each isolate, $100 \mu 1$ of overnight fresh bacterial cell suspension was added to $20 \mathrm{ml}$ of sterile peptone yeast extract broth (which contained per litter peptone $=10 \mathrm{~g}$; beef extract $=3 \mathrm{~g} ; \mathrm{NaCl}=5 \mathrm{~g}$; L-tryptophan $=50 \mathrm{mg}$; distilled water $=1 \mathrm{~L} ; \mathrm{p}^{\mathrm{H}}=7$ ) in to $50 \mathrm{ml}$ sterilized falcon tubes, and was incubated for $72 \mathrm{~h}$ at $28^{\circ} \mathrm{C}$ in the dark by wrapping with aluminum foil.

After $72 \mathrm{~h}$ of incubation, cultured isolates were taken and centrifuged at $10,000 \mathrm{rpm}$ for 10 $\mathrm{min}$, and $10 \mathrm{ml}$ of the supernatant was withdrawn and put in $15 \mathrm{ml}$ test tube, and then added $5 \mathrm{ml}$ of Salkawaski reagent which contained a 1:1 ratio of $(50 \mathrm{ml}, 35 \%$ perchloric acid, and $1 \mathrm{ml}$ per $1.5 \mathrm{M}$ of $\mathrm{FeCl}_{3}$ solution. The culture falcon tubes were incubated at $37^{\circ} \mathrm{C}$ in the dark for $1 \mathrm{~h}$. Formation of red color in the medium was then considered as the ability of IAA production of isolates.

Produced IAA was quantified by measuring their optical density (OD) at absorbance of $530 \mathrm{~nm}$ with the standard of produced IAA and the results for each isolates were recorded and repeat the test for positive isolate was conducted at 3 concentrations of tryptophan $(25 \mathrm{mg} / \mathrm{L} ; 100$ $\mathrm{mg} / \mathrm{L}$ and $150 \mathrm{mg} / \mathrm{L}$ ) and the OD was measured at $530 \mathrm{~nm}$ and compared at which high concentration IAA was produced.

\section{Test for Ammonia Production}

Isolates which had the potential to solubilize phosphorus and able to produce IAA were further tested for Ammonia $\left(\mathrm{NH}_{3}\right)$ production following the method described. ${ }^{10}$

Then, $100 \mu$ l of pure overnight culture of fresh bacterial cell suspensions were inoculated in $30 \mathrm{ml}$ of peptone broth (4\%) in triplication and were incubated at $28^{\circ} \mathrm{C}$ for 72 hours. After the incubation, $2 \mathrm{ml}$ Nessler's reagent which contained (potassium iodide $=50 \mathrm{gm}$; saturated mercuric chloride $=35 \mathrm{ml}$; distilled water $=25 \mathrm{ml}$; potassium hydroxide $(40 \%)=400 \mathrm{ml})$ was added using serological pipette.

The formation of yellow to brown precipitate showed the presence of $\mathrm{NH}_{3}$. For the control, Nessler's reagent was added to the broth without inoculums. Then, the produced $\mathrm{NH}_{3}$ was quantified by reading the $\mathrm{OD}$ at $530 \mathrm{~nm}$ comparing the potential of isolate with the standard of produced ammonia.

\section{Evaluation of Bacterial Isolates for Sorghum Growth Promotion Inoculum Preparation}

The isolates which have the potential to pass the screening test were considered for greenhouse evaluation by following the method described ${ }^{26}$, Flasks which have the capacity of $250 \mathrm{ml}$ were selected and filled with $150 \mathrm{ml}$ of nutrient broth and were sterilized with steam sterilization method, and cooled down overnight by putting at the hood. Then, $200 \mu \mathrm{l}$ of pure overnight suspension culture was added to the broth and incubated at incubator shaker for $72 \mathrm{~h}$ by adjusting rpm 150 per minute and temperature $28^{\circ} \mathrm{c}$. After $72 \mathrm{~h}$ of incubation, the standard concentration was adjusted at $1 \times 10^{-9}$

\section{Greenhouse Evaluation}

Growth promoting potential of the isolated PGPR bacteria was evaluated with completely randomized design with 3 replications using Teshale sorghum genotype which has low growth or higher Striga susceptible trait. The seeds were surface sterilized by the following procedure, washing the seed by distilled water 3 times and then washing it with $1.5 \%$ of $5 \%$ bleach by adding 2 drops of Tween 20. Finally, the seeds were rinsed five times in sterile water and germinated by soaking them at the plate with Whatman paper and with $3 \mathrm{ml}$ of distilled sterilized water.

Pots with the capacity of $1.5 \mathrm{~kg}$ were filled with $1 \mathrm{~kg}$ of sterilized soil (steam sterilization for 20 minute) and planted with three germinated 
seeds, with three replications for one genotype. Therefore, each test isolate pot had 9 plants in a completely randomized design. The bacterial inoculums $100 \mathrm{ml}$ with the standard concentration of $1 \times 10^{-9}$ were applied after the first and the second leaf appeared and developed.

The temperature of the greenhouse was maintained at $28{ }^{\circ} \mathrm{C}$ and watering was done $(500$ $\mathrm{ml}$ regularly at evening time with 3 days gap). The plants were harvested 5 weeks after the first inoculation. For the control, only distilled water was used instead of the bacterial suspension. The growth-promoting ability of microbial isolates were determined based on the data recorded on plant shoot height, plant shoot dry and fresh weight, and root length, root dry and fresh weight.

Data on plant shoot height and root lengths were recorded by measuring the height and length using ruler. Data on plant shoot and root fresh weight of both plant shoot height and root lengths were recorded by measuring the weight by sensitive electronic balance in the unit of gram. Data for dry weight of shoot and the roots were recorded by made dry the sample using dry heat oven at $65^{\circ} \mathrm{c}$ for 4 hours and measured the weight using sensitive electronic balance in the unit of gram. The percent (\%) of bacterial performance for all agronomic parameters compared to the control was determined using the following formula.

$$
\begin{aligned}
\text { Increased } \% & =[\text { Treatmentvalue-controlvalue } / \\
& \text { controlvalue }] \times 100
\end{aligned}
$$

\section{Biochemical and Morphological Characterization}

The ability of the isolates in gram staining, sugar utilization with or without gas production, and catalase tests were determined according to the methods described in detail below, in addition to that screening each species by their selective media.

\section{Sugar Utilization Test}

The ability of the isolates to utilize carbohydrates and sugars as a carbon source was determined according to the following protocol. ${ }^{33}$, one litter basal media was prepared. It contains (10 g peptone broth, $5 \mathrm{~g}$ sodium chloride, $1 \mathrm{~g}$ beef extract, $7.2 \mathrm{ml}$ phenol red, $10 \mathrm{~g}$ each tested carbohydrate (glucose, lactose, and sucrose) and 1
L sterilized water). Then, autoclaved and dispensed to $2 \mathrm{ml}$ basal media to sterilized ELISA plate, and was added $100 \mu \mathrm{l}$ of pure culture bacterial suspension of tested isolate, and was incubated for $24 \mathrm{~h}$ at $28^{\circ} \mathrm{C}$. The color changed from purple to yellow was the positive indicator for utilizing the carbon source.

\section{Catalase Reaction Test}

Overnight culture of PGPR was thoroughly mixed with $3 \% \mathrm{H}_{2} \mathrm{O}_{2}$ on microscopic slides ${ }^{33}$. The slides were examined for the bubble formation and showed catalase positive but did not form bubble catalase negative.

\section{Gram Staining}

The gram staining procedure was carried out according to the method described ${ }^{33}$. As briefly described, $100 \mu$ l overnight culture of bacterial cell suspension was added to surface sterilized microscopic slide, and it was smeared gently. Then, the slides were inserted into crystal violate and washed by sterilized water. Again, the slides were inserted to iodine solution and washed by sterilized water. Then, the slides were inserted into $97 \%$ of ethanol and washed by sterilized water. Finally, the slides were inserted into safranin solution and washed by sterilized water and examined using the 100x objective lens microscopy and purple colored bacteria were gram positive, whereas read colored or colorless bacteria were gram negative.

\section{Morphological characterization}

A loop full active cell suspension of the isolates were streaked on nutrient agar media and incubated for 24 hours at $28^{\circ} \mathrm{c}$ then the colony morphology was recorded.

\section{Classification of Bacterial Genera}

Based on the above chemical test the bacterial genera was classified in to different bacterial genera which was based on the characteristics of the bacterial genera which fulfilled the test result.

\section{Statistical Analysis}

The significance effect of PGPR isolates on sorghum growth promoting potential were determined by using ANOVA table in a completely randomized design (CRD) based on the factor used. $F$ values and means were made by using the Tukey men separation model at $P=0.01$ probability levels and the correlation analysis for agronomic parameters were done. 


\section{RESULTS AND DISCUSSION}

\section{Isolation of PGPR Bacteria}

In the current study a total of 117 PGPR isolates were isolated. Out of the $117 ; 33(28 \%)$ isolates solubilized phosphate, out of the 33 ; $26(78.78 \%)$ isolates produced IAA, out of the 26; $18(69.23 \%)$ isolates produced ammonia. From the total of $117 ; 18(15 \%)$ isolates solubilized phosphate, produced IAA and ammonia and selected as a potential PGPR. These might be due to potential of each isolates depending on their individual sources plant genome and taxonomic genera. However, those 18 isolates (Table 4), had different potential in primary growth promoting trait. These might be due to the potential of each isolate depending on their source genotype and environmental condition. ${ }^{13}$. The previous work ${ }^{4}$ described that, due to nutrient availability, plant rhizosphere has heterogeneous and functional microbes. As indicated in previous research such as rice. ${ }^{30,37}$, Wheat ${ }^{27}$; Sorghum ${ }^{26}$; Mung bean ${ }^{6}$; Ginger $^{13}$ and Maize ${ }^{1}$; plant growth promoting Rhizosphere bacteria can promote or increase plant growth, particularly cereal and horticultural tuber crops either through direct or indirect mechanisms.

Eighteen isolates were compared for their potential for phosphate solubilization, IAA production and ammonia production tests and greenhouse evaluation was conducted to check whether they promote sorghum growth or not using Teshale sorghum genotype. It was the most Striga susceptible sorghum variety with low growth rate compared to other sorghum genotypes as described ${ }^{5,39}$. The purpose of using different sorghum genotypes to isolate PGPR was that most of PGPR are plant genotype and soil environmental condition dependent according ${ }^{13}$ who isolated Ginger growth promoting bacteria from different Ginger genotype and those isolates were classified as under different genera and species.

\section{Detection of Plant Growth Promoting (PGP)} Traits

Phosphate Solubilization Test

Out of 117 isolates; 33 isolates solubilized phosphate. However, from 33 isolates 18 isolates produced IAA and Ammonia in addition to solubilizing the phosphate, but all 18 isolates had statistically a significance different phosphate solubilization potential at $\mathrm{P}=0.01$. 
Tri-calcium phosphate (TCP) is used in phosphate solubilization test as a source of phosphate in an insoluble form as described ${ }^{22}$. These significance difference might be due to the isolates which had production potential of phosphatase enzyme can solubilize insoluble phosphate into a solubilized and usable form directly by plants or Phosphate solubilizing bacteria reduces $\mathrm{pH}$ of rhizosphere soils by releasing organic acids which dissolve phosphate mineral through anion exchange ${ }^{35}$. This process increases the availability of phosphorus for plant uptake; but isolates which can't produce organic acid have low phosphate solubilization potential compared isolates capable of production of organic acid (Table 4). No isolates were solubilized TCP which are isolated from the bulk soil, this might be due to PGPR needs root exudates molecule which secretes from the plant to the rhizosphere soil and used as a carbon source that makes to colonize the root by PGPR which can solubilize TCP. But in the bulk soil, there is no root exudates molecule.

\section{IAA production Test}

Twenty six of the isolates were found to be able to produced IAA at $50 \mathrm{mg} / \mathrm{L}$ Tryptophan concentration out of 33 tested isolate by converted the yellow color broth to red-pink color. However, 18 isolates were the most potential isolates for IAA production and highly significant at $\mathrm{P}=0.01$.
All 18 isolates produced IAA between the concentration ranges of $1.1 \mathrm{mg} / \mathrm{ml}$ to $1.9 \mathrm{mg} /$ $\mathrm{ml}$ at $50 \mathrm{mg} / \mathrm{l}$ tryptophan ((Table 4). However, as the result indicated, those 18 selected isolates had a significant different IAA production potential at different concentration of tryptophan $(25,50,100$, $150 \mathrm{mg} / \mathrm{L}$ ). At $50 \mathrm{mg} / \mathrm{L}$ tryptophan concentration, isolate G6E29 from Jigurti sorghum genotype and soil from Humera produced the highest amount of IAA $1.9 \mathrm{mg} / \mathrm{ml}$. The lowest concentration was recorded from isolate G3E19 from ETWS 91242(Benishangul Region) isolated from the soil at Shoa Robit that produced $1.1 \mathrm{mg} / \mathrm{ml}$. However, the concentration of tryptophan became lower to $25 \mathrm{mg} / \mathrm{L}$ of tryptophan IAA production became low for all 18 isolates. As indicated on ((Table 4), isolates that produced IAA at $25 \mathrm{mg} / \mathrm{ml}$ tryptophan showed lower IAA production than from $50 \mathrm{mg} / \mathrm{L}$ tryptophan.

In general, isolates from Humera soil, with all 12 sorghum genotype rhizosphere, had the higher IAA production potential belongs to Pseudomonas and Bacillus bacterial genera, whereas isolate from Shoa Robit and Kemise soil with 12 sorghum genotype rhizosphere had the lower IAA production potential in all tryptophan concentration which means plant genotype and soil type also affect the production of $1 \mathrm{AA}$ in addition to tryptophan concentration ${ }^{40}$.

Table 2. Sorghum genotype used to isolate PGPR

\begin{tabular}{llll}
\hline $\begin{array}{l}\text { Sorghum } \\
\text { genotype }\end{array}$ & Source/Region & Character & Selection Criteria \\
\hline Degalit & Tigray Region & Local landrace & Landrace and widely used \\
ETWS 90754 & Amhara Region & Wild type & Wild type \\
ETWS 91242 & Beneshangul Region & Wild type & Wild type \\
Framida & Purdue University & Striga resistance & Striga resistant and widely used \\
Hora_Doldy2 & Landrace & LGS & Landrace and LGS \\
Jigurti & Landrace & HGS & Landrace, widely used and HGS \\
Misikir & Drought Score & Drought tolerant & Drought tolerant \\
S35 & ICRISAT & Stay green & Stay green or Drought tolerant \\
Shanquired & China & Striga susceptible & HGS and model for striga susceptible \\
SR5-Ribka & IBC & Striga resistant and & Striga resistant and Fusarium compatibility \\
& & Fusarium compatibility & \\
SRN39 & Purdue University & Striga resistance & Striga resistant and widely used \\
Teshale & ICRISAT & Best released varieties & Widely used \\
\hline
\end{tabular}

Were, LGS = low germination stimulant, HGS $=$ High germination stimulant and IBC $=$ International Biodiversity Center 


\section{Ammonia Production Test}

Only 18 out of 26 isolates were able to produced Ammonia with the produced ammonia and 18 isolates had more potential for Ammonia production and all 18 isolates had a significant different ammonia production potential at $\mathrm{P}=0.01$.

In general isolate from the soils at Humera and Kemise with all sorghum genotypes had produced higher amount of ammonia compared to the isolate from the soil at Shoa Robit and belongs to Pseudomona and Bacillus bacterial genera. These might be due to the soil type and sorghum genotype affect the production potential of ammonia produced PGPR isolate association with sorghum ${ }^{40},{ }^{29}$ reported that isolates from all genotype of wheat produced the same amount of Ammonia. on the other hand reported ammonia production potential of rhizosphere bacteria depends on the soil nutrient availability and species of bacteria; which is contradicting to the current study ${ }^{27,36}$. However, based on the current study, ammonia production of an isolate from different sorghum genotype and soil sample had different ammonia production potential; these might be due to the soil type and nutrient availability affect the ammonia production of PGPR bacteria.
The analysis of variances of PGPR bacteria for sorghum growth related parameters such as Phosphate Solubilization, IAA production and Ammonia production tests were presented in (Table 5) below respectively. Mean squares were highly significant at $(p=0.01)$ for all parameters indicating that each isolate differed in the growth related trait cause variation which agreed with the finding of ${ }^{27}$. This might be due to the genetic makeup of the isolates and source genotype as well as the soil with the environmental condition. ${ }^{13}$

The mean separation analysis and analysis of variances of plant growth promoting rhizosphere bacteria for sorghum growth related parameter such Phosphate Solubilization Test, Indole Acetic Acid Production Test and Ammonia Production Test were presented in (Table 4) respectively. Significant differences were detected between each isolate for all of the studied parameter which indicating that each isolate differed in the growth related trait cause variation which agreed with the finding of. ${ }^{27}$ Entry mean squares were significant at $p<0.01$ for all parameter, these might be due to the genetic makeup of the isolate and source genotype as well as the soil with the environmental condition.

Table 3. Selected eighteen potential isolates with their soil sources, sources genotype along with their trait

\begin{tabular}{llll}
\hline Isolate code & Soil source & Source genotype & Genotype trait \\
\hline G4E29 & Humera & Framida & Striga resistance \\
G5E29 & Humera & Hora - Doldy2 & LGS and Landrace \\
G6E29 & Humera & Jigurti & HGS and Landrace \\
G8E29 & Humera & S35 & Stay green \\
G11E29 & Humera & SRN39 & Striga resistance \\
G12E29 & Humera & Teshale & Best released varieties \\
G2E19 & Shoa Robit & ETWS 90754 & Wild type \\
G3E19 & Shoa Robit & ETWS 91242 & Wild type \\
G4E19 & Shoa Robit & Framida & Striga resistance \\
G5E19 & Shoa Robit & Hora - Doldy2 & LGS \\
G6E19 & Shoa Robit & Jigurti & HGS \\
G8E19 & Shoa Robit & S35 & Stay green \\
G9E19 & Shoa Robit & Shanquired red & Striga susceptible \\
G10E19 & Shoa Robit & SR5-Ribka & Fusarium compatibility \\
G12E19 & Shoa Robit & Teshale & Best released varieties \\
G3E40 & Kemise & ETWS 91242 & Wild type \\
G4E40 & Kemise & Framida & Striga resistance \\
G6E40 & Kemise & Jigurti & HGS \\
& &
\end{tabular}


Greenhouse Evaluation of PGPR for Sorghum Growth Promotion

All the 18 isolates have significantly increased all the agronomic parameters relative to the control. However, some of the isolates had highly significant compared to the others at $\mathrm{p}=$ 0.01(Table 6).

Isolate G6E29 was isolated from Jigurti (landrace sorghum genotype) and soil from Humera; it was significantly increased plant shoot height by $75 \%$. Whereas isolate G4E19 was isolated from Framida sorghum genotype and the soil from Shoa Robit; it was significantly increased plant shoot by 74\%. Next to G6E29 and G4E19, three isolates (G4E29, G8E19 and G4E40) showed a significant increase in plant shoot height, and isolated from the Rhizosphere of Framida and S35 sorghum genotypes along with the soil collected at Humera, Shoa Robit and Kemise and significantly increased plant shoot height by $73 \%, 70 \%$ and $68 \%$ respectively. As described in (Table 6), the rest isolates also significantly increased the plant shoot height compared to the control. But compared to each other, they had lower potential relative to the above one; these might be due to the tested sorghum genetic makeup and environments are comfortable for PGPR to increase the plant shoot height. ${ }^{4,5,32}$ reported that all the tested isolates did not significantly increase the plant shoot height compared to the control which is contradicting to the current study. However, in the current study, all the isolates were increased the plant shoot height compared to the control with different plant shoot height increasing potential. The report ${ }^{27}$ analogous with the current study which reported that all selected potential isolates increased plant shoot height compared to the control.

Three isolates (G4E19, G8E19 and G6E19) significantly increased the plant shoot fresh weight. G4E19 was isolated from the Rhizosphere of Framida sorghum genotype, and the soil at Shoa Robit; it was significantly increased the plant shoot

Table 4. Mean separation analysis result for PSB (Cm), AMP (OD) and IAA (OD) production

\begin{tabular}{|c|c|c|c|c|c|c|}
\hline Isolate & $\begin{array}{l}\text { PSB } \\
(\mathrm{mm})\end{array}$ & $\begin{array}{l}\text { AMP } \\
\text { (OD) }\end{array}$ & $\begin{array}{c}\text { IAA at } \\
25 \mathrm{mg} / \mathrm{L} \mathrm{T} \\
(\mathrm{OD})\end{array}$ & $\begin{array}{c}\text { IAA at } \\
50 \mathrm{mg} / \mathrm{L} \mathrm{T} \\
(\mathrm{OD})\end{array}$ & $\begin{array}{c}\text { IAA at } \\
100 \mathrm{mg} / \mathrm{L} \mathrm{T} \\
\text { (OD) }\end{array}$ & $\begin{array}{c}1 \mathrm{AA} \text { at } \\
150 \mathrm{mg} / \mathrm{L} \mathrm{T} \\
(\mathrm{OD})\end{array}$ \\
\hline G4E29 & $22.6^{\mathrm{BC}}$ & $12.5^{\mathrm{E}}$ & $0.24^{\mathrm{HG}}$ & $1.84^{\mathrm{BC}}$ & $2.01^{\mathrm{N}}$ & $0.12^{\mathrm{M}}$ \\
\hline G5E29 & $20.1 \mathrm{~B}^{\mathrm{CDE}}$ & $11.3^{\mathrm{I}}$ & $0.55^{\mathrm{C}}$ & $1.55^{\mathrm{FE}}$ & $2.21^{\mathrm{L}}$ & $0.23^{\mathrm{KL}}$ \\
\hline G6E29 & $28.1^{\mathrm{A}}$ & $16.8^{\mathrm{A}}$ & $0.72^{\mathrm{B}}$ & $1.99^{\mathrm{A}}$ & $2.88^{\mathrm{A}}$ & $2.99^{\mathrm{A}}$ \\
\hline G8E29 & $22.5^{\mathrm{BC}}$ & $9.2^{\mathrm{O}}$ & $0.34^{\mathrm{F}}$ & $1.74^{\mathrm{CD}}$ & $1.99^{\circ}$ & $1.11^{\mathrm{B}}$ \\
\hline G11E29 & $18.3^{\mathrm{DE}}$ & $11.6^{\mathrm{H}}$ & $0.51^{\mathrm{CD}}$ & $1.55^{\mathrm{FE}}$ & $2.31^{\mathrm{K}}$ & $0.99^{\mathrm{C}}$ \\
\hline G12E29 & $19.8^{\mathrm{BCDE}}$ & $10.6^{\mathrm{K}}$ & $0.86^{\mathrm{A}}$ & $1.65^{\mathrm{DE}}$ & $2.52^{\mathrm{E}}$ & $0.52^{\mathrm{F}}$ \\
\hline G2E19 & $19.2^{\mathrm{CDE}}$ & $9.7^{\mathrm{M}}$ & $0.21^{\mathrm{H}}$ & $1.24^{\mathrm{IJ}}$ & $2.64^{\mathrm{B}}$ & $0.63^{\mathrm{E}}$ \\
\hline G3E19 & $22.3^{\mathrm{BCD}}$ & $9^{\mathrm{P}}$ & $0.64^{\mathrm{B}}$ & $1.15^{\mathrm{J}}$ & $2.54^{\mathrm{D}}$ & $0.23^{\mathrm{L}}$ \\
\hline G4E19 & $20.1^{\mathrm{BCDE}}$ & $13.2^{\mathrm{C}}$ & $0.32^{\mathrm{FG}}$ & $1.45^{\mathrm{G}}$ & $2.61^{\mathrm{C}}$ & $0.25^{\mathrm{J}}$ \\
\hline G5E19 & $18.6^{\mathrm{CDE}}$ & $8.98^{\mathrm{P}}$ & $0.42^{\mathrm{E}}$ & $1.34^{\mathrm{HI}}$ & $2.33^{\mathrm{J}}$ & $0.66^{\mathrm{D}}$ \\
\hline G6E19 & $17.9^{\mathrm{E}}$ & $12.2^{\mathrm{F}}$ & $0.30^{\mathrm{FG}}$ & $1.55^{\mathrm{EF}}$ & $2.42^{\mathrm{H}}$ & $0.22^{\mathrm{L}}$ \\
\hline G8E19 & $23.5^{\mathrm{B}}$ & $11.9^{\mathrm{G}}$ & $0.24^{\mathrm{HG}}$ & $1.40^{\mathrm{GH}}$ & $2.46^{\mathrm{G}}$ & $0.33^{\mathrm{I}}$ \\
\hline G9E19 & $21.1^{\mathrm{BCDE}}$ & $12.5^{\mathrm{E}}$ & $0.88^{\mathrm{A}}$ & $1.85^{\mathrm{B}}$ & $2.21^{\mathrm{L}}$ & $0.24 \mathrm{~J}^{\mathrm{K}}$ \\
\hline G10E19 & $20.3^{\mathrm{BDCE}}$ & $9.9^{\mathrm{L}}$ & $0.12^{\mathrm{I}}$ & $1.45^{\mathrm{FG}}$ & $2.11^{\mathrm{M}}$ & $0.12^{\mathrm{M}}$ \\
\hline G12E19 & $19.5^{\mathrm{RCDE}}$ & $10.9^{\mathrm{J}}$ & $0.54^{\mathrm{C}}$ & $1.67^{\mathrm{D}}$ & $2.51^{\mathrm{F}}$ & $0.45^{\mathrm{H}}$ \\
\hline G3E40 & $22.8^{\mathrm{BC}}$ & $12.6^{\mathrm{D}}$ & $0.44^{\mathrm{ED}}$ & $1.24^{\mathrm{IJ}}$ & $2.64^{\mathrm{B}}$ & $0.23^{\mathrm{KL}}$ \\
\hline G4E40 & $20.8^{\mathrm{BCDE}}$ & $9.5^{\mathrm{N}}$ & $0.12^{\mathrm{I}}$ & $1.35^{\mathrm{GH}}$ & $2.11^{\mathrm{M}}$ & $0.66^{\mathrm{D}}$ \\
\hline G6E40 & $21.2^{\mathrm{BCDE}}$ & 14.38 & $0.11^{\mathrm{I}}$ & $1.65^{\mathrm{DE}}$ & $2.35^{\mathrm{I}}$ & $0.48^{\mathrm{G}}$ \\
\hline MSD & 4.1 & 0.045 & 0.08 & 0.10 & 0.003 & 0.012 \\
\hline $\mathrm{CV}$ & 6.45 & 0.12 & 6.2 & 2.12 & 0.04 & 0.66 \\
\hline $\mathrm{R} 2$ & $82 \%$ & $99 \%$ & $99 \%$ & $98 \%$ & $99 \%$ & $99 \%$ \\
\hline Alpha & 0.01 & 0.01 & 0.01 & 0.01 & 0.01 & 0.01 \\
\hline
\end{tabular}

Where, $\mathrm{PSB}=$ phosphate solubilization, $\mathrm{IAAP}=$ Indole acetic acid production, $\mathrm{AMP}=\mathrm{Ammonia}$ production Test and $\mathrm{T}=$ Tryptophan, $\mathrm{mm}=$ millimeter, $\mathrm{OD}=$ optical density 


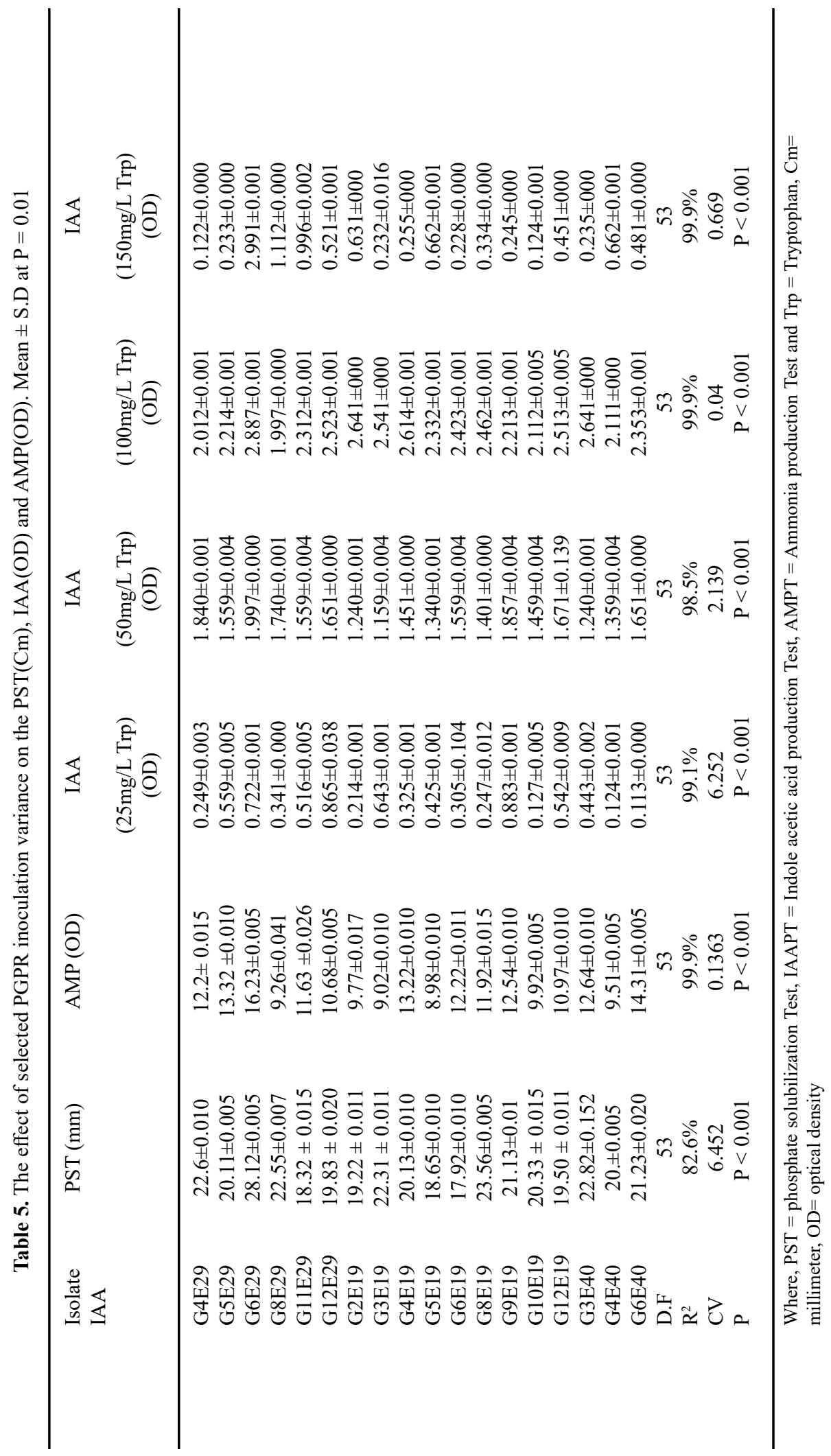


fresh weight by $54 \%$. G8E19 was isolated from the rhizosphere of S35 sorghum genotype, and the soil collected from Shoa Robit; it was significantly increased the plant shoot fresh weight by $52 \%$, and G6E19 was isolated from Jigurti landrace sorghum genotype, and Shoa Robit soil; it was significantly increased plant shoot fresh weight by $48 \%$. G5E 19 was isolated from Hora-Doldy2 Ethiopian landrace sorghum genotype and the soil at Shoa Robit; it was significantly increased the plant shoot fresh weight by $48 \%$. The remaining isolates also significantly increased the plant shoot fresh weight compared to the control. However, compared to each other, they had lower potential relative to the above, may be due to sorghum genetic makeup of the tested genotype and favorable environmental conditions required by PGPR. Each isolate might have also different potential based on their Genome. The isolates increased the plant shoot height but not the plant shoot fresh weight which is contradicted to the current study ${ }^{27}$. But here, all 18 isolates increased plant shoot height and plant shoot fresh weight compared to the control. Isolates that increase the plant shoot height also increase plant shoot fresh weight which is related to the current study ${ }^{42}$.

Three isolates; such as G4E19, G8E19 and G6E29 are significantly increased the plant shoot dry weight. G4E19 was isolated from the Rhizosphere of Framida sorghum genotype, and the soil at Shoa Robit; it was significantly increased the plant shoot dry weight by $119 \%$. G8E19 was isolated from the rhizosphere of S35 sorghum genotype, and the soil at Shoa Robit, it was significantly increased plant shoot dry weight by $116 \%$. G6E29 was isolated from Rhizosphere of Jigurti landrace sorghum, and soil at Humera; it was significantly increased plant shoot dry weight by $109 \%$. Such statistically significance difference might be due to the tested sorghum genetic makeup

Table 6. Mean separation analysis result for each isolate in favor of agronomic data (PSH, PSFW, PSDW, RL, RFW and RDW) at $\mathrm{P}=0.01$

\begin{tabular}{|c|c|c|c|c|c|c|}
\hline Isolate & $\begin{array}{l}\mathrm{PSH} \\
(\mathrm{Cm})\end{array}$ & $\begin{array}{c}\text { PSFW } \\
(\mathrm{gm})\end{array}$ & $\begin{array}{c}\text { PSDW } \\
\text { (gm) }\end{array}$ & $\begin{array}{c}\mathrm{RL} \\
(\mathrm{Cm})\end{array}$ & $\begin{array}{l}\text { RFW } \\
(\mathrm{gm})\end{array}$ & $\begin{array}{l}\text { RDW } \\
(\mathrm{gm})\end{array}$ \\
\hline G4E29 & $35.2^{\mathrm{bc}}$ & $11.5^{\mathrm{ef}}$ & $8.2^{\mathrm{c}}$ & $36.2^{\mathrm{bc}}$ & $15.4^{\mathrm{bc}}$ & $9.5^{\mathrm{bc}}$ \\
\hline G5E29 & $33.2^{\mathrm{d}}$ & $11.4^{\mathrm{ef}}$ & $5.2^{1}$ & $34.2^{\mathrm{de}}$ & $15.1^{\mathrm{cd}}$ & $8.8^{\mathrm{de}}$ \\
\hline G6E29 & $35.5^{\mathrm{a}}$ & $13.8^{\mathrm{bc}}$ & $8.8^{\mathrm{ab}}$ & $37.8^{\mathrm{a}}$ & $16.3^{\mathrm{ab}}$ & $9.7^{\mathrm{b}}$ \\
\hline G8E29 & $31.4^{\mathrm{f}}$ & $10.4^{\mathrm{h}}$ & $7.0^{\mathrm{fg}}$ & $34.1^{\mathrm{de}}$ & $14.9^{\mathrm{cd}}$ & $9.1^{\mathrm{cd}}$ \\
\hline G11E29 & $33.2^{\mathrm{d}}$ & $10.8^{\mathrm{gh}}$ & $7.8^{\mathrm{cd}}$ & $33.8^{\mathrm{e}}$ & $14.1^{\mathrm{de}}$ & $8.8^{\mathrm{e}}$ \\
\hline G12E29 & $30.2^{\mathrm{h}}$ & $9.8^{\mathrm{i}}$ & $5.5^{\mathrm{kl}}$ & $32.2^{\mathrm{f}}$ & $12.2^{\mathrm{fg}}$ & $7.2^{\mathrm{g}}$ \\
\hline G2E19 & $31.7^{\mathrm{f}}$ & $11.1^{\mathrm{fg}}$ & $6.3^{\text {hi }}$ & $29.8^{\mathrm{g}}$ & $11.3^{\mathrm{gh}}$ & $5.1^{\mathrm{i}}$ \\
\hline G3E19 & $32.2^{\mathrm{e}}$ & $11.8^{\mathrm{de}}$ & $6.9^{\mathrm{fg}}$ & $35.2^{\mathrm{cd}}$ & $14.2^{\mathrm{de}}$ & $6.5^{\mathrm{h}}$ \\
\hline G4E19 & $35.2^{\mathrm{a}}$ & $14.3^{\mathrm{a}}$ & $9.2^{\mathrm{a}}$ & $37.2^{\mathrm{ab}}$ & $16.4^{\mathrm{ab}}$ & $9.7^{\mathrm{b}}$ \\
\hline G5E19 & $33.5^{\mathrm{d}}$ & $13.2^{\mathrm{c}}$ & $8.2^{\mathrm{c}}$ & $28.2^{\mathrm{h}}$ & $13.5^{\mathrm{e}}$ & $8.3^{\mathrm{f}}$ \\
\hline G6E19 & $33.1^{\mathrm{d}}$ & $13.8^{\mathrm{ab}}$ & $8.8^{\mathrm{ab}}$ & $31.3^{\mathrm{f}}$ & $12.2^{\mathrm{fg}}$ & $9.3^{\mathrm{c}}$ \\
\hline G8E19 & $34.6^{\mathrm{b}}$ & $14.1^{\mathrm{a}}$ & $9.1^{\mathrm{a}}$ & $35.6^{\mathrm{c}}$ & $12.3^{\mathrm{fg}}$ & $8.7^{\mathrm{e}}$ \\
\hline G9E19 & $30.7^{\mathrm{g}}$ & $9.7^{\mathrm{ij}}$ & $5.8^{\mathrm{jk}}$ & $25.1^{\mathrm{i}}$ & $10.2^{\mathrm{ij}}$ & $6.2^{\mathrm{h}}$ \\
\hline G10E19 & $34.2^{\mathrm{c}}$ & $11.7^{\mathrm{de}}$ & $7.4^{\mathrm{de}}$ & $32.0^{\mathrm{f}}$ & $13.2^{\mathrm{ef}}$ & $9.2^{\mathrm{cd}}$ \\
\hline G12E19 & $32.4^{\mathrm{e}}$ & $10.5^{\mathrm{h}}$ & $7.1^{\mathrm{ef}}$ & $28.2^{\mathrm{h}}$ & $9.1^{\mathrm{j}}$ & $6.5^{\mathrm{h}}$ \\
\hline G3E40 & $30.3^{\mathrm{h}}$ & $9.7^{\mathrm{ij}}$ & $6.7^{\mathrm{gh}}$ & $27.4^{\mathrm{h}}$ & $7.2^{\mathrm{k}}$ & $6.4^{\mathrm{h}}$ \\
\hline G4E40 & $34.2^{\mathrm{bc}}$ & $12.1^{\mathrm{d}}$ & $8.6^{\mathrm{b}}$ & $36.2^{\mathrm{bc}}$ & $17.1^{\mathrm{a}}$ & $12.1^{\mathrm{a}}$ \\
\hline G6E40 & $31.4^{\mathrm{f}}$ & $10.5^{\mathrm{h}}$ & $6.2^{\mathrm{ij}}$ & $24.4^{\mathrm{i}}$ & $10.2^{\mathrm{hi}}$ & $6.1^{\mathrm{h}}$ \\
\hline Control & $20.3^{\mathrm{i}}$ & $9.3^{\mathrm{j}}$ & $4.2^{\mathrm{m}}$ & $21.2^{\mathrm{j}}$ & $9.8^{\mathrm{ji}}$ & $3.4^{\mathrm{j}}$ \\
\hline $\mathrm{CV}$ & 0.428 & 1.388 & 1.804 & 1.305 & 2.732 & 1.727 \\
\hline $\mathrm{R}^{2}$ & $99.8 \%$ & $99.3 \%$ & $99.4 \%$ & $99.5 \%$ & $98.9 \%$ & $99.7 \%$ \\
\hline MSD & 0.426 & 0.495 & 0.404 & 1.275 & 1.089 & 0.425 \\
\hline
\end{tabular}

Where, PSH = Plant Shoot Height; PSFW = Plant Shoot Fresh Weight; PSDW = Plant Shoot Dry Weight; $\mathrm{RL}=$ Root Length; RFW = Root Fresh Weight and RDW = Root Dry Weight; CV = Coefficient of Variation; $\mathrm{MSD}=$ Minimum Significance Difference, $\mathrm{Cm}=$ centimeter, $\mathrm{gm}=$ gram . 
and conducive environment for PGPR isolates for plant soot dry weight ${ }^{5}$. PGPR bacterial genera might have different potential based on their genome to increase the plant shoot dry weight ${ }^{31}$. The above ground plant biomass growth promoting potential of PGPR also affected by environmental condition, soil type and greenhouse condition ${ }^{20,40}$. All the tested PGPR increased in shoot dry weight by $80 \%$ compared to the control which but in the current study all tested PGPR increased in different amount ${ }^{5,19}$. Isolates increase plant shoot dry weight in different amount which is comparable to the current study ${ }^{27}$.

The two isolates (G6E29 and G4E19) significantly increased root length. G6E29 was isolated from the Rhizosphere of Jigurti landrace sorghum genotype, and from the soil at Humera; it significantly increased root length by $78 \%$,

Table 7. The effect of PGPR inoculation variance on sorghum agronomic data (PSH, PSFW, PSDW, RL, RFW and RDW). Mean + SD at $\mathrm{P}=0.01$

\begin{tabular}{lcccccc}
\hline Isolate & PSH $(\mathrm{Cm})$ & PSFW(gm) & PSDW(gm) & RL(Cm) & RFW(gm) & RDW(gm) \\
\hline G4E29 & $34.3 \pm 0.10$ & $11.5 \pm 0.03$ & $8.2 \pm 0.03$ & $36.2 \pm 0.06$ & $15.4 \pm 0.05$ & $9.5 \pm 0.05$ \\
G5E29 & $33.2 \pm 0.08$ & $11.4 \pm 0.15$ & $5.2 \pm 0.06$ & $34.2 \pm 0.03$ & $15.1 \pm 0$ & $8.8 \pm 0.03$ \\
G6E29 & $35.5 \pm 0.05$ & $13.4 \pm 0.11$ & $8.8 \pm 0.03$ & $37.8 \pm 0.01$ & $16.3 \pm 0.05$ & $9.7 \pm 0.03$ \\
G8E29 & $31.4 \pm 0.05$ & $10.4 \pm 0.03$ & $7.0 \pm 0.06$ & $34.1 \pm 0.03$ & $14.9 \pm 0$ & $9.1 \pm 0.03$ \\
G11E29 & $33.2 \pm 0.08$ & $10.8 \pm 0.03$ & $7.8 \pm 0.06$ & $33.8 \pm 0.03$ & $14.1 \pm 0.03$ & $8.8 \pm 0.03$ \\
G12E29 & $30.2 \pm 0.12$ & $9.8 \pm 0.03$ & $5.5 \pm 0.05$ & $32.2 \pm 0.08$ & $12.2 \pm 0.05$ & $7.2 \pm 0.03$ \\
G2E19 & $31.7 \pm 0.08$ & $11.1 \pm 0.06$ & $6.3 \pm 0.01$ & $29.8 \pm 0.03$ & $11.3 \pm 0$ & $5.1 \pm 0.03$ \\
G3E19 & $32.2 \pm 0.06$ & $11.8 \pm 0.03$ & $6.9 \pm 0$ & $35.2 \pm 0.13$ & $14.2 \pm 0.03$ & $6.5 \pm 0.03$ \\
G4E19 & $35.2 \pm 0.03$ & $14.3 \pm 0.11$ & $9.2 \pm 0.05$ & $37.2 \pm 0.03$ & $16.4 \pm 0.10$ & $9.7 \pm 0.08$ \\
G5E19 & $33.5 \pm 0.05$ & $13.2 \pm 0.08$ & $8.2 \pm 0.05$ & $28.2 \pm 0.08$ & $13.5 \pm 0.86$ & $8.3 \pm 0.05$ \\
G6E19 & $33.1 \pm 0.03$ & $13.8 \pm 0.03$ & $8.8 \pm 0.03$ & $31.3 \pm 0.11$ & $12.2 \pm 0.08$ & $9.3 \pm 0.05$ \\
G8E19 & $34.6 \pm 0.08$ & $14.1 \pm 0.03$ & $9.1 \pm 0.03$ & $35.6 \pm 0.03$ & $12.3 \pm 0.11$ & $8.7 \pm 0.08$ \\
G9E19 & $30.7 \pm 0.08$ & $9.7 \pm 0.05$ & $5.8 \pm 0.03$ & $25.1 \pm 0.03$ & $10.2 \pm 0.05$ & $6.2 \pm 0.08$ \\
G10E19 & $34.2 \pm 0$ & $11.7 \pm 0.10$ & $7.4 \pm 0.089$ & $32.0 \pm 0.03$ & $13.2 \pm 0.089$ & $9.2 \pm 0.03$ \\
G12E19 & $32.4 \pm 0.12$ & $10.5 \pm 0.05$ & $7.1 \pm 0.03$ & $28.2 \pm 0.08$ & $9.1 \pm 0.03$ & $6.5 \pm 0.02$ \\
G3E40 & $30.3 \pm 0.05$ & $9.7 \pm 0.11$ & $6.7 \pm 0.15$ & $27.4 \pm 0.05$ & $7.2 \pm 0.05$ & $6.4 \pm 0.15$ \\
G4E40 & $34.2 \pm 0.12$ & $12.1 \pm 0.06$ & $8.6 \pm 0.12$ & $36.2 \pm 0.08$ & $17.1 \pm 0.03$ & $12.1 \pm 0.06$ \\
G6E40 & $31.4 \pm 0.05$ & $10.5 \pm 0.20$ & $6.2 \pm 0.05$ & $24.4 \pm 0.06$ & $10.2 \pm 0.06$ & $6.1 \pm 0.06$ \\
Control & $20.3 \pm 0.12$ & $9.3 \pm 0.12$ & $4.2 \pm 0.12$ & $21.2 \pm 0.10$ & $9.8 \pm 0.03$ & $3.4 \pm 0.05$ \\
DF & 56 & 56 & 56 & 56 & 56 & 56 \\
MSD & 0.426 & 0.495 & 0.404 & 1.275 & 1.089 & 0.425 \\
P & $\mathrm{P}<0.001$ & $\mathrm{P}<0.001$ & $\mathrm{P}<0.001$ & $\mathrm{P}<0.001$ & $\mathrm{P}<0.001$ & $\mathrm{P}<0.001$ \\
\hline
\end{tabular}

Where, $\mathrm{DF}=$ Degree of Freedom; M.S.D $*=$ Minimum Significance Difference PH $=$ Plant Height; PFW = Plant Fresh Weight; PDW = Plant Dry Weight; RL $=$ Root Length; RFW $=$ Root Fresh Weight and RDW $=$ Root Dry Weight, $\mathrm{Cm}=$ centimeter, gm $=$ gram

Table 8. Correlation relationship for PSH, PSFW, PSDW, RL, RFW and RDW at P=0.01

\begin{tabular}{lcccccc}
\hline & PH & PFW & PPDW & RL & RFW & RDW \\
\hline PH & & & & & \\
PFW & $0.674 * *$ & & & & \\
PDW & $0.769 * * *$ & $0.832 * * *$ & & & \\
RL & $0.747 * *$ & $0.611 * *$ & $0.655 * *$ & & \\
RFW & $0.559 * *$ & $0.564 * *$ & $0.509 * *$ & $0.819 * * *$ & \\
RDW & $0.768^{* * *}$ & $0.616^{* *}$ & $0.746 * *$ & $0.793 * * *$ & $0.783 * * *$ \\
& & & & & \\
\hline
\end{tabular}

Where $* *$ moderate (significance), ${ }^{* * *}$ strong (highly significance), PSH $=$ Plant Shoot Height; PSFW = Plant Shoot Fresh Weight; PSDW= Plant Shoot Dry Weight; RL = Root Length; RFW = Root Fresh Weight and RDW = Root Dry Weight 
whereas G4E19 was isolated from the Rhizosphere of Framida sorghum genotype, and the soil at Shoa Robit; it was significantly increased the root length by $75 \%$. The three isolates such as G4E29, G4E19 and G4E40 have significantly increased the root length next to G6E29 and G4E19. G4E29 was isolated from the Rhizosphere of Framida sorghum genotype, and the soil at Humera, it was significantly increased the root length by $71 \%$. G4E19 was isolated from the combination of Framida sorghum genotype, and the soil at Shoa Robit, it was significantly increased the root length by $75 \%$. G4E40 was isolated from Framida sorghum genotype and the soil collected at Kemise, it was significantly increased the root length by $71 \%$. The other isolates also had significant increasing effect in the root length compared to the control. But compared to each other, they had lower potential relative to the above one, these difference might be due to the tested sorghum genetic makeup and environmental condition is comfortable for PGPR, as well as each isolate might have different potential based on their genome to increase the root length or the sorghum genotype that have more carbon root exudates which are used for PGPR to colonize the root and increase the root length ${ }^{8}$. The most of the isolates increased the root length in the same amount $16 \mathrm{~cm}$ compared to the control ${ }^{19,5}$. The isolates were significantly increased the root length in different potential which is similar to the current study reported that all the isolates increased the root length significantly with different manner depending on source genotype and soil sample ${ }^{27}$.

The three isolates such as G4E40, G6E29 and G4E29 have significantly increased the root fresh weight. G4E40 was isolated from the Rhizosphere of Framida sorghum genotype, and the soil at Kemise; it was increased the root fresh weight by $74 \%$, G6E29 was isolated from the Rhizosphere of Jigurti landrace sorghum genotype, and the soil collected at Humera; it was significantly increased root fresh weight by $66 \%$ and G4E29 was isolated from the Rhizosphere of Framida sorghum genotype, and the soil collected at Humera; it was significantly increased the root fresh weight by $56 \%$. The two isolates (G5E29 and G8E29) were isolated from the rhizosphere Hora-Doldy2 and S35 sorghum genotype with the combination of soil from Humera. Compared to the control, both isolates were increased the root fresh weight by $54 \%$ and $52 \%$ respectively. The rest isolates also had significantly increased in

Table 9. Biochemical and morphological characterization of 18 selected potential isolates

\begin{tabular}{|c|c|c|c|c|c|c|c|c|}
\hline Isolate & Glucose & Lactose & Sucrose & $\begin{array}{l}\text { Gram } \\
\text { stain }\end{array}$ & shape & $\begin{array}{c}\text { Catalase } \\
\text { test }\end{array}$ & $\begin{array}{c}\text { Colony } \\
\text { morphology }\end{array}$ & Genera \\
\hline G4E29 & + & + & + & - & rods & - & Button shaped & Pseudomona \\
\hline G5E29 & + & + & + & - & rods & - & Button shaped & Pseudomona \\
\hline G6E29 & + & + & + & - & rods & - & Button shaped & Pseudomona \\
\hline G8E29 & + & + & + & - & rods & + & Serrated margins & Azotobacter \\
\hline G11E29 & + & + & + & - & rods & + & Serrated margins & Azotobacter \\
\hline G12E29 & + & + & + & - & rods & + & Serrated margins & Azotobacter \\
\hline G2E19 & + & + & + & - & rods & + & Serrated margins & Azotobacter \\
\hline G3E19 & + & + & + & - & rods & + & Serrated margins & Azotobacter \\
\hline G4E19 & + & + & + & - & rods & - & Button shaped & Pseudomona \\
\hline G5E19 & + & + & + & + & rods & + & Serrated margins & Bacillus \\
\hline G6E19 & + & + & + & - & rods & - & Button shaped & Pseudomona \\
\hline G8E19 & + & + & + & - & rods & - & Button shaped & Pseudomona \\
\hline G9E19 & + & + & + & - & rods & - & Button shaped & Pseudomona \\
\hline G10E19 & + & + & + & - & rods & - & Button shaped & Pseudomona \\
\hline G12E19 & + & + & + & + & rods & + & Serrated margins & Bacillus \\
\hline G3E40 & + & + & + & - & rods & + & Serrated margins & Azotobacter \\
\hline G4E40 & + & + & + & + & rods & + & Serrated margins & Bacillus \\
\hline G6E40 & + & + & + & + & rods & + & Serrated margins & Bacillus \\
\hline
\end{tabular}

Were, $+=$ can utilize the tested Carbone, the gram positive isolate and can produced catalase enzyme; - = gram negative isolate or can't produce catalase enzyme 
the root fresh weight compared to the control. But compared to each other, they had a lower potential relative to the above one. But two isolates (G12E19 and G3E40) no significant for root fresh weight. Compared to the control, the root fresh weight decreased by $7 \%$ and $26 \%$ respectively from the control; but they had a significant increasing effect for the rest agronomic parameter. These might be due to the isolate was not contented association to the tested genotype or affect the environmental condition for root fresh weight ${ }^{5}$. All the isolates increased the root length also increased the root fresh weight which is contradict to the current study ${ }^{2,27}$. However, the current study reports that all the isolates significantly increased the root fresh weight with different amount, these might be due to the tested sorghum genotype genetic makeup and environmental condition is comfortable for PGPR, as well as each isolate might have different potential based on their genome and colonize the root to increase the root fresh weight or the sorghum genotype that more carbon root exudates which is used for PGPR to colonize the root ${ }^{40}$.

Intended for root dry weight, isolate G4E40 which was isolated from the Rhizosphere of Framida sorghum genotype, and soil at Kemise; it was significantly increased the dry weight of root by $256 \%$. The three isolates (G4E29, G6E29 and G4E19) were isolated from the Rhizosphere of Framida and Jigurti sorghum genotype with a combination of soil collected from Humera and Shoa Robit; they have significantly increased the root dry weight by $256 \%, 185 \%$ and $185 \%$ respectively. The other isolate also significantly increased the root dry weight compared to the control, these might be due to the tested sorghum genetic makeup and environmental condition is contented for PGPR function, as well as each isolate might have different potential based on their genome to increase the root dry weight (Table 6) compared to each other ${ }^{9}$. The isolates were isolated from different crop rhizosphere and genotype increased root dry weight differently which is similar to the current studyl, 6,28. To the contradict, all the isolates did not significantly increase all the agronomic parameter which is isolated from single soil sample and sorghum genotype ${ }^{27,28}$. However, in the current study, all the isolates were significantly increased all the parameter in a significance variation, except two Bacillus and
Azotobacter bacterial genera (G12E19 and G3E40).

The two isolates such as G6E29 and

G4E19 have increased all the sex parameters isolated from the Rhizosphere of Jigurti and Framida sorghum genotype, and the soil collected from Humera and Shoa Robit also belongs to Pseudomona bacterial genera. Bacteria isolated from the soil collected at Humera and Shoa Robit increased all the parameter compared to each other. PGPR bacteria which are isolated from the Humera soil had the higher growth promoting potential compared to the soil collected from Shoa Robit, whereas PGPR bacteria which are isolated from the soil at Kemise had the growth promoting potential but low growth promoting potential compared to the bacteria which are isolated from soil at Humera and Shoa Robit, these might be the soil and environmental condition effect the growth promoting potential PGPR bacteria ${ }^{5,19}$

All the isolates had the growth promoting potential compared to the control but had different growth promoting potential depending on the source genotype. So, bacteria isolated from Framida and Jigurti sorghum genotype significantly increased all the parameter followed by bacteria isolated from the landrace's sorghum genotype having growth promoting potential compared to the bacteria isolated from the other sorghum genotype, these might be due to the genetic makeup of source sorghum genotypes are affect the type and potential of PGPR. Bacteria isolated from sorghum Framida, Jigurti and landrace sorghum genotype with the combination soil collected at Humera and Shoa Robit significantly increased the six parameters such as: plant shoot height, plant shoot fresh weight, plant shoot dry weight, root length, root fresh weight and root dry weight compared to bacteria isolated from the rest of sorghum genotype and soil collected at Humera, these might be due to plant genotype and soil type together with environmental condition affect the potential of PGPR.

The analysis of variances of plant growth promoting rhizosphere bacteria for sorghum growth and growth-related parameter; such as plant shoot height, plant shoot fresh weight, plant shoot dry weight, root length, root fresh and dry weight related traits were presented in (Table 7). Significant differences were detected between each isolate for all of the studied parameters which 
indicates that each isolate differed in the growth promoting potential for Teshale sorghum genotype cause variation which goes with the finding of Indris ${ }^{27}$. Entry mean squares were significant $(p<0.01)$ for all agronomic parameter; these might be due to all the tested PGPR rhizosphere bacteria have different growth promoting potential depending their source.

Plant height, plant fresh and dry weight, root length, root fresh, and dry weight positively correlated among each other (Table 8). The Pearson correlation coefficient as weak, moderate and strong for values ranging from 0 to $\pm 0.29, \pm 0.3$ to \pm 0.69 and \pm 0.7 to \pm 1.0 , respectively. So all the agronomic parameters (Plant height, plant fresh and dry weight, root length, root fresh, and dry weight) exhibited a positive correlation with strong and moderate relation, these might be due to growth promoting rhizobacteria can produced appropriately all growth related trait and affected all agronomic parameter in an the same manner. The current study results were following the finding of Indris and Khalid ${ }^{27,28}$. Some of reported that plant height was negatively correlated with root length and fresh weight, but in the current study all the agronomic parameters were positively correlated $^{1,5,6}$.

Biochemical and Morphological characterization

In the current study, a total of 18 potential isolates were obtained from sorghum genotype based on the fact that they fulfilled all growth promoting characteristics. As described in (Table 9). All the tested isolates were rood shaped and utilized carbon source. Isolate G5E29, G12E19, G6E40 were gram - positive, whereas the rest isolates were gram-negative. Isolate G4E29, G5E29, G6E29, G4E19, G6E19, G8E19, G9E19, G10E19 and G12E19 were catalase-negative, whereas G8E29, G11E29, G12E29, G2E19, G3E19, G5E19, G3E40, G4E40 and G6E40 were catalase-positive. All the eighteen isolates were groped in two colony morphology such as button and serrated margins shaped.

Eight isolates (G4E29, G5E29, G6E29, G4E19, G6E19, G8E19, G9E19 and G10E19) were classified under the taxonomic genera of Pseudomonas. Six isolates (G8E29, G11E29, G12E29, G2E19, G3E19 and G3E40) were classified under the taxonomic genera of
Azotobacter and four isolates (G5E19, G12E19, G4E40 and G6E40) were classified under the taxonomic genera of Bacillus. Pseudomonas, Azotobacter and Bacillus were associated with the Rhizosphere of sorghum ${ }^{27}$. The Actinomycetes were also associated in addition to Pseudomonas, Azotobacter and Bacillus genera ${ }^{5}$. So, in the current study, the majority of the isolates from Landrace sorghum genotype and all the 3 soil samples were classified under Pseudomonas. Azotobacter PGPR bacteria were associated with the developed variety of sorghum genotype with all soil samples; Bacillus PGPR bacteria were associated with Striga susceptible sorghum genotype. So, sorghum genotype affected the association of PGPR bacteria at rhizosphere of sorghum, might be depending on the sorghum genotype and soil sample, taxonomic classification and the Carbon source utilization of growth promoting bacteria is diverse. Based on the current study the Pseudomonas PGPR genera are the beast performance for both plant growth related screening test and sorghum growth promoting performance in greenhouse. However, the growth promoting potential of Pseudomonas genera had a significance difference depending on the source sorghum genotype and soil type. Based on the current study the Pseudomonas genera have the greatest potential for both growth related trait such as phosphate solubilization test, IAA production test and ammonia production test along with the potential of in all agronomic parameter for greenhouse evaluation and followed by Bacillus genera in all growth related trait and growth parameter.

\section{CONCLUSION}

Nowadays, it is very important to improve sorghum production and productivity using plant growth promoting rhizosphere bacteria in Ethiopian agriculture. The result of the current study revealed that the objective such as to isolate and screen isolated PGPR for growth promoting trait and evaluate their growth promoting potential in the greenhouse and identify potential growth promoting PGPR using biochemical and morphological characterization which are isolated from 12 sorghum genotype by cultivating on 3 collected soil samples from Northern part of 
Ethiopia. A total of 117 rhizosphere bacteria were isolated from 12 sorghum genotype rhizosphere sample.

All the 117 isolates were subjected to growth promoting test; such as phosphate solubilization test using PVK culturing media and 33 isolates solubilized phosphate, in addition to phosphate solubilization, all 33 isolates were subjected for IAA production test using different concentration of tryptophan; such as $25 \mathrm{mg} / \mathrm{L}, 50$ $\mathrm{mg} / \mathrm{L}, 100 \mathrm{mg} / \mathrm{L}$, and $150 \mathrm{mg} / \mathrm{L}$ of tryptophan. Twenty-six isolates produced IAA from the total 33 isolate PGPR. The production potential of each IAA produced 26 isolates increased from $25 \mathrm{mg} / \mathrm{L}$ to $100 \mathrm{mg} / \mathrm{L}$ of tryptophan concentration but decreased using $150 \mathrm{mg} / \mathrm{L}$ of tryptophan concentration, except one isolate, G6E29, which increased IAA production at $150 \mathrm{mg} / \mathrm{L}$ of tryptophan. Based on the current study, the higher IAA production scored at tryptophan concentration of $100 \mathrm{mg} / \mathrm{L}$. In addition to phosphate solubilization and IAA production test, all the 26 isolates were subjected to ammonia production test using Nessler's reagent. Eighteen isolates produced ammonia from all 26 tested PGPR based on the screening test. Eighteen isolates (G4E29, G5E29, G6E29, G8E29, G11E29, G12E29, G2E19, G3E19, G4E19, G5E19, G6E19, G8E19, G9E19, G10E19, G12E19, G3E40, G4E40 and G6E40) were selected based on those isolates which solubilize phosphate, produce IAA and produce ammonia. Those potential selected 18 isolates were subjected to further greenhouse evaluation and biochemical characterization.

Eighteen of the most potential isolates were evaluated in a greenhouse by adding $1 \times 10^{-19}$ standard concentrations on Teshale sorghum genotype at Holeta National Agricultural Biotechnology Research Center. Plant shoot height, plant shoot fresh and dry weight, root length, root fresh, and dry weight were collected after 35 days of inoculation. Analysis of variance revealed the presence of significant variation among isolates for all studied traits. Mean square of all isolates for all parameter was significant indicating that all the isolates significantly promote sorghum growth.

For plant shoot height, all the 18 isolates significantly increased plant height when compared to the control. But when compared to each other, two isolates G6E29 and G4E19 significantly increased the plant shoot height better than the other. For plant shoot fresh and dry weight, all the isolates significantly increased plant shoot fresh and dry weight compared to the control but G6E29, G4E19 and G8E19 the potential one compared to each other. For root length, all the isolates significantly increased root length when compared to the control, but when compared to each other, they have different potential for root length growth, and G6E29 and G4E19 were the most important ones in this respect. For root fresh and dry weight, all the isolates significantly increased the root fresh and dry weight compared to the control, except two isolate, G12E19 and G3E40, which are nonsignificance for the root fresh weight compared to the control. The isolates G6E29, G4E19 and G4E40 significantly increased the root fresh and dry weight.

Pearson correlation coefficient analysis revealed that plant soot height, plant shoot fresh and dry weight, root length, root fresh and dry weight growth and growth-related traits had a highly significant $(p<0.01)$ positive correlations with each other. Based on the findings of the current study, the following recommendations and feature line of work have been suggested.

Isolates with good sorghum growth promoting potentialities were characterized and the best 2 efficient isolates (G6E29 and G4E19) were identified. The results are promising for the design of potentially active sorghum growth promoting PGPR strain which would be beneficial for improvement of sorghum production and productivity for sustainable agriculture. The experiment was conducted using soil collected from the Northern part of Ethiopia; it is realistic to conduct similar experiments for other parts of Ethiopia across wider ranges of agro ecology to get other potential PGPR strain. The experiment was conducted at in vivo level for sorghum only; it is realistic to carry out a similar experiment for other crops across wider ranges of agro ecology. Furthermore, assessing different types of effective and compatible PGPR strains along with different sources of crop and environment to increase crop production efficiency and grain yield of sorghum and other cereal crop should require further investigation in the future. 


\section{REFERENCES}

1. Abedinzadeh, M.; Etesami, H. and Alikhani, H. Characterization of rhizosphere and endophytic bacteria from roots of Maize (Zea mays L.) plant irrigated with wastewater with biotechnological potential in agriculture. Biotechnology Research. 2019; 21(5): 305-315. https://doi.org/10.1016/j. btre.2019.e00305

2. Agbodjato, A.; Noumavo, A.; Adjanohoun, A.; Agbessi, L. and Baba-Moussa, L.. Synergistic effects of plant growth promoting rhizobacteria and chitosan on in vitro seeds germination, greenhouse growth, and nutrient uptake of maize (Zea mays L.). Biotechnology Research International. 2016; 5(12): 89-110. http://dx.doi. org/10.1155/2016/7830182

3. Ahemad, M. and Kibret, M. Mechanisms and Applications of plant growth promoting rhizobacteria: current perspective. Journal of King Saud University-Science. 2014; 26(1):1-20. https://doi.org/10.1016/j.jksus.2013.05.001

4. Ahmad, F.; Ahmad, I. and Khan, M. Screening of free-living rhizospheric bacteria for their multiple plant growth promoting activities. Microbiological Research. 2008; 163(2):173-181. https://doi.org/10.1016/j.micres.2006.04.001

5. Andreote, F.; Rocha, U.; Araújo, W.; Azevedo, J. and van Overbeek, L. Effect of bacterial inoculation, plant genotype and developmental stage on root-associated and endophytic bacterial communities in potato (Solanum tuberosum). Antonie Van Leeuwenhoek. 2010; 97(4):389-399. DOI 10.1007/s10482-010-9421-9

6. Anjum, M.; Zahir, Z.; Arshad, M. and Ashraf, M.. Isolation and screening of rhizobia for auxin biosynthesis and growth promotion of mung bean (Vigna radiata L.) seedlings under axenic conditions. Soil \& Environment. 2011; 30(1):18-26. https://www.researchgate.net/ profile/ZahirZahir/publication/285981560_

7. Atera, E.; Itoh, K. and Onyango, J. Evaluation of ecologies and severity of Striga weed on rice in sub-Saharan Africa. Agriculture and biology journal of North America. 2011; 2(5): 752-760. https://repository.maseno.ac.ke/ handle/123456789/2068

8. Bloemberg, G. and Lugtenberg, B. Molecular basis of plant growth promotion and biocontrol by rhizobacteria. Current opinion in plant biology. 2001; 4(4): 343-350. https://doi. org/10.1016/S1369-5266(00)00183-7

9. Cakmakçi, R.; Dönmez, F.; Aydýn, A. and Dahin, F. Growth promotion of plants by plant growthpromoting rhizobacteria under greenhouse and two different field soil conditions. Soil Biology and Biochemistry. 2006; 38(6):1482-1487. https://doi.org/10.1016/j.soilbio.2005.09.019

10. Cappuccino, J.G. and Sherman, N. Biochemical activities of microorganisms. Microbiology, A Laboratory Manual. The Benjamin/Cummings Publishing Co. California, USA.1992, pp.188247. https://doi.org/10.2166/wst.2001.0036

11. Cook, R.r. Advances in plant health management in the twentieth century. Annual review of phytopathology. 2002; 38(1): 95-116. https://doi. org/10.1146/annurev.phyto.38.1.95

12. CSA. Agricultural Sample Survey 2017/2018: Report on Area and Production of Major Crops (Private Peasant Holdings, Meher Season). 2018. Volume I. Statistical Bulletin, Addis Ababa, Ethiopia. https://www.ajol.info/index.php/ejas/ article/view/189560

13. Dinesh, R.; Anandaraj, M.; Kumar, A.; Bini, Y.; Subila, K. and Aravind, R.Isolation, characterization, and evaluation of multi-trait plant growth promoting rhizobacteria for their growth promoting and disease suppressing effects on ginger. Microbiological Research. 2015; 173(6): 34-43. https://doi.org/10.1016/j. micres.2015.01.014

14. FAO. F. Food and agriculture organization of the United Nations. Retrieved on. 2021. 18. https:// ageconsearch.umn.edu/record/309801/

15. FAOSTAT. Database of agricultural production. FAO Statistical Databases. 2006. https:// ageconsearch.umn.edu/record/309801/

16. FAOSTAT. Database of agricultural production. FAO Statistical Databases. 2012. https:// ageconsearch.umn.edu/record/309801/

17. Gebretsadik, R.; Shimelis, H.; Laing, M.; Tongoona, P. and Mandefro, N. A diagnostic appraisal of the sorghum farming system and breeding priorities in Striga infested agroecologies of Ethiopia. Agricultural Systems. 2014; 123(9): 54-61. https://doi.org/10.1016/j. agsy.2013.08.008

18. Geremew, G.; Adugna, A.; Taye, T.; Tesfaye, T.; Ketema, B. and Michael, H. Development of sorghum varieties and hybrids for dryland areas of Ethiopia. Uganda Journal of Agricultural Sciences. 2004. 9(1): 594-605. file:///C:/ Users/DELL/AppData/Local/Temp/135536Article\%20Text-363329-1-10-20160512.pdf

19. Giongo, A.; Beneduzi, A.; Ambrosini, A.; Vargas, L.; Stroschein, M.; Eltz, F.; Bodanese, M. and Passaglia, L. Isolation and characterization of two plant growth-promoting bacteria from the rhizoplane of a legume (Lupinus albescens) in sandy soil. Revista Brasileira de Ciência do Solo. 2010; 34(2):361-369. https://e-repository.org/rbl/ vol.23/iss.2/4.pdf 
20. Glick, B. Plant growth-promoting bacteria: mechanisms and applications. Scientifica. 2012; 20(12):20-35. https://doi. org/10.6064/2012/963401

21. Gottumukkala, V.; Miralpeix, E.; Nick, A.; Meyer, L.; Cata, J.; Lasala, J.; Mena, G.; Iniesta, M.; Salvo, G. and Ramirez, P. A call for new standard of care in perioperative gynecologic oncology practice: impact of enhanced recovery after surgery (ERAS) programs. Gynecologic oncology. 2016; 141(2): 371-378. https://doi. org/10.1016/j.ygyno.2016.02.019

22. Gouda, S., Kerry, R.G., Das, G., Paramithiotis, S., Shin, H.S. and Patra, J.K. Revitalization of plant growth promoting rhizobacteria for sustainable development in agriculture. Microbiological research. 2018; 206: 131-140. https://doi. org/10.1016/j.micres.2017.08.016

23. Hamdali, H.; Hafidi, M.; Virolle, M. and Ouhdouch, Y. Rock phosphate-solubilizing Actinomycetes: screening for plant growthpromoting activities. World Journal of Microbiology and Biotechnology. 2008; 24(11): 2565-2575. https://link.springer.com/ article/10.1007/s11274-008-9817-0

24. Haussmann, B.; Hess, D.; Welz, H. and Geiger, H. Improved methodologies for breeding Striga resistant sorghums. Field Crops Research. 2000a. 66(3):195-211. https://doi.org/10.1016/S03784290(00)00076-9

25. Hayat, R.; Ali, S.; Amara, U.; Khalid, R. and Ahmed, I. Soil beneficial bacteria and their role in plant growth promotion: a review. Annals of Microbiology. 2010. 60(4): 579-598. https://link. springer.com/article/10.1007/s13213-010-01171

26. Hussein, M.; Ali, R.; Hamad, H. and Malash, G. Potential of using green adsorbent of heavy metal removal from aqueous solutions: adsorption kinetics, isotherm, thermodynamic, mechanism and economic analysis. Ecological Engineering. 2016. 91(7): 317-332. https://doi.org/10.1016/j. ecoleng.2016.03.015

27. Idris, A.; Labuschagne, N. and Korsten, L. Efficacy of rhizobacteria for growth promotion in sorghum under greenhouse conditions and selected modes of action studies. The Journal of Agricultural Science. 2009. 147(1): 17-30. https://doi.org/10.1017/S0021859608008174

28. Khalid, A.; Arshad, M. and Zahir, Z. Screening plant growth promoting rhizobacteria for improving growth and yield of wheat. Journal of Applied Microbiology. 2004. 96(3): 473-480. https://doi.org/10.1046/j.13652672.2003.02161.X

29. Mahmood, S.; Daur, I.; AlSolaimani, S.; Ahmad,
S.; Madkour, M.; Yasir, M.; Hirt, H.; Ali, S. and Ali, Z. Plant growth promoting rhizobacteria and silicon synergistically enhance salinity tolerance of mung bean. Frontiers in plant science. 2016. 7(4): 876-889. https://www.frontiersin.org/ articles/10.3389/fpls.2016.00876/full

30. Mayak, S.; Tirosh, T. and Glick, B. Stimulation of the growth of tomato, pepper and mung bean plants by the plant growth-promoting bacterium Enterobacter cloacae CAL3. Biological agriculture \& horticulture. 2010. 19(3): 261274. https://doi.org/10.1080/01448765.2001.97 54929

31. Mehnaz, S.; Mirza, M.; Haurat, J.; Bally, R.; Normand, P.; Bano, A. and Malik, K. Isolation and $16 \mathrm{~S}$ rRNA sequence analysis of the beneficial bacteria from the rhizosphere of rice. Canadian journal of microbiology. 2001. 47(2): 110-117. https://doi.org/10.1139/w00-132

32. Noumavo, P.; Kochoni, E.; Didagbé, Y.; Adjanohoun, A.; Allagbé, M.; Sikirou, R.; Gachomo, E.; Kotchoni, S. and Babamoussa, L. Effect of different plant growth promoting rhizobacteria on maize seed germination and seedling development. American Journal of Plant Sciences. 2013. 4(5): 1013-1021. DOI:10.4236/ajps.2013.45125

33. Pikovskaya, R.h. Mobilization of phosphorus in soil in connection with vital activity of some microbial species. Mikrobiologiya. 1948. 17(1): 362-370. https://ci.nii.ac.jp/naid/10026513896/

34. Prescot, H.r. Laboratory Exercises In Microbiology, $5^{\text {th }}$ ed. The McGraw-Hill companies, United Kingdom. 2002. pp.256321. http://125.212.201.8:6008/handle/ DHKTYTHD_123/2722

35. Sherathia, D.; Dey, R.; Thomas, M.; Dalsania, T.; Savsani, K. and Pal, K. Biochemical and molecular characterization of DAPG-producing plant growth-promoting rhizobacteria (PGPR) of groundnut (Arachis hypogaea L.). Legume Research An International Journal, .2016; 39(4):614-622. https://www.indianjournals. com/ijor.aspx ?target $=$ ijor: 1 r \&volume $=39 \&$ issue $=4 \&$ article $=021$.

36. Sivasankari, J.k. Indole-3-Acetic Acid Production by the Bacterial Strains Isolated from Vermicomposts in the Presence and Absence of Tryptophan. International Journal of Innovative Research in Science, Engineering and Technology.2016; 5(5): 92-107. https://www. researchgate.net/profile/Balayogan-Sivasankari/ publication/304571775

37. Souza, R.; Ambrosini, A. and Passaglia, L. Plant growth-promoting bacteria as inoculants in agricultural soils. Genetics and 
molecular biology. 2015; 38(4): 401-419. https://scholar.google.com/scholar?hl=en\&as $\mathrm{sdt}=0 \% 2 \mathrm{C} 5 \& \mathrm{q}=\mathrm{S}$ ouza $\% 2 \mathrm{C}+\mathrm{R} . \% 3 \mathrm{~B}+$ Ambrosini $\% \quad 2 \mathrm{C}+\mathrm{A} .+$ and $+\mathrm{Passaglia} \%$ $2 \mathrm{C}+\mathrm{L} . \% 2 \mathrm{C}+2015$.

38. Thakuria, D.; Talukdar, N.; Goswami, C.; Hazarika, S.; Boro, R. and Khan, M. Characterization and screening of bacteria from rhizosphere of rice grown in acidic soils of Assam. Current Science. 2004; 24(6): 978-985. https://www.jstor.org/stable/24109284

39. Tsegaye, Z.; Gizaw, B.; Tefera, G.; Feleke, A.; Chaniyalew, S.; Alemu, T. and Assefa, F. Isolation and biochemical characterization of Plant Growth Promoting (PGP) bacteria colonizing the rhizosphere of Tef crop during the seedling stage. Biomed J Sci \& Tech Res. 2019; 14(2): 1586-1597. https://www.researchgate.net/ profile/Zerihun-Tsegaye/publication/332309204
40. Vejan, P.; Abdullah, R.; Khadiran, T.; Ismail, S. and Nasrulhaq, A. Role of plant growth promoting rhizobacteria in agricultural sustainability a review. Molecules. 2016; 21(5): 573-584. https:// doi.org/10.3390/molecules21050573

41. Vivas, A.; Biro, B.; Ruizlozano, J.; Barea, J. and Azcon, R. Two bacterial strains isolated from a Zn-polluted soil enhance plant growth and mycorrhizal efficiency under Zn-toxicity. Chemosphere. 2006; 62(9): 1523-1533. https:// doi.org/10.1016/j.chemosphere.2005.06.053

42. Zinniel, D.; Lambrecht, P.; Harris, N.; Feng, Z.; Kuczmarski, D.; Higley, P.; Ishimaru, C.; Arunakumari, A.; Barletta, R. and Vidaver, A. Isolation and characterization of endophytic colonizing bacteria from agronomic crops and prairie plants. Appl. Environ. Microbiol. 2002; 68(5): 2198-2208. https://doi.org/10.1128/ aem.68.5.2198-2208.2002 